\title{
Appealing to Goodwill or YOLO-Promoting Conservation Volunteering to Millennials
}

\author{
Gwendelyn S. Nisbett ${ }^{1}$ - Marianna Strzelecka ${ }^{2}$
}

Published online: 26 December 2016

(C) The Author(s) 2016. This article is published with open access at Springerlink.com

\begin{abstract}
Volunteer travel opportunities are more plentiful than ever and are now offered worldwide, with conservation projects being an increasingly popular choice. Some of the emerging questions in this field are concerned with the effective communication of these opportunities to young people. One theory that could guide the creation of these persuasive campaigns for conservation volunteering is regulatory focus theory. By adopting this theory, we reveal yet another possibility for understanding motivations of conservation volunteers. Results of the experiment suggest promotion messages are better received (more persuasive) because they induce expectations in line with general view of conservation volunteering as a hedonic experience. Moreover, this study is the first one of its kind to show this important effect of environmental attitudes on individuals' responses to promotional messages about conservation volunteering travel.
\end{abstract}

Résumé Les occasions de voyage bénévole sont plus nombreuses que jamais et désormais offertes partout dans le monde, les projets de conservation en constituant un choix de plus en plus populaire. Dans ce domaine, des questions émergentes portent sur la communication efficace de ces occasions aux jeunes. Une des théories qui pourraient orienter la création de ces campagnes de persuasion pour le bénévolat dans le domaine de la conservation est la théorie à focalisation réglementaire. En l'adoptant, nous pouvons mieux comprendre les motivations des bénévoles œuvrant dans le domaine de la conservation. Les résultats de l'expérimentation suggèrent

Marianna Strzelecka

marianna.strzelecka@lnu.se

Gwendelyn S. Nisbett

Gwen.nisbett@unt.edu

1 Mayborn School of Journalism, University of North Texas, 1155 Union Circle \#311460, Denton, TX 76203, USA

2 School of Business and Economics, Linnaeus University, 39182 Kalmar, Sweden 
que les messages promotionnels sont mieux reçus (plus persuasifs), car ils suscitent des attentes alignées sur l'opinion générale du public sur le bénévolat de conservation comme expérience édénique. Qui plus est, la présente étude est la première en son genre à démontrer cet important effet des attitudes environnementales sur les réactions des individus aux messages promotionnels concernant les voyages bénévoles axés sur la conservation.

Zusammenfassung Es gibt heute mehr Möglichkeiten für Volunteer-Reisen denn je zuvor, und sie werden inzwischen in der ganzen Welt angeboten, wobei Umweltschutzprojekte immer beliebter werden. Einige Fragen in diesem Bereich beschäftigen sich damit, wie junge Menschen effektiv über diese Möglichkeiten informiert werden können. Eine Theorie, die die Entwicklung von überzeugenden Kampagnen für eine ehrenamtliche Arbeit im Umweltschutzbereich leiten könnte, ist die Theorie des regulatorischen Fokus. Durch Anwendung dieser Theorie zeigen wir eine weitere Möglichkeit, die Motivationen von Ehrenamtlichen im Umweltschutzbereich nachzuvollziehen. Die Ergebnisse des Experiments weisen darauf hin, dass Werbebotschaften besser aufgenommen werden (sie sind überzeugender), weil sie Erwartungen schüren, die mit der allgemeinen Ansicht übereinstimmen, dass eine ehrenamtliche Tätigkeit im Umweltschutzbereich eine hedonische Erfahrung ist. Darüber hinaus ist diese Studie die erste ihrer Art, die diesen wichtigen Effekt der Umwelteinstellungen auf die Reaktionen von Personen auf Werbebotschaften über Volunteer-Reisen im Umweltschutzbereich aufzeigt.

Resumen Las oportunidades de viaje para voluntarios son más numerosas que nunca y ahora se ofrecen en todo el mundo, siendo los proyectos de conservación una elección cada vez más popular. Algunas de las preguntas que surgen en este campo se refieren a la comunicación efectiva de estas oportunidades a la gente joven. Una teoría que podría guiar la creación de estas campañas persuasivas para el voluntariado de la conservación es la teoría del foco regulador. Al adoptar esta teoría, revelamos sin embargo otra posibilidad para comprender las motivaciones de los voluntarios de la conservación. Los resultados del experimento sugieren que los mensajes de promoción son mejor recibidos (más persuasivos) porque incluyen expectativas en línea con la opinión general del voluntariado de la conservación como una experiencia hedonista. Asimismo, el presente estudio es el primero de su clase en mostrar este importante efecto de las actitudes medioambientales sobre las respuestas de los individuos a mensajes promocionales sobre los viajes para el voluntariado de la conservación.

Keywords Conservation volunteering - Communication - Regulatory focus theory

Volunteer travel opportunities are more plentiful than ever and are now offered worldwide, with conservation projects being an increasingly popular choice. Volunteer travelers are "tourists who volunteer in an organized way to undertake holidays" (Wearing 2001, p. 1). Among many projects such as alleviating the 
material poverty of some groups in society, community development, and research into aspects of society are projects focused on rehabilitation of endangered ecosystems and research or habitat development that contributes to long-term nature conservation goals. Lorimer (2009) identifies conservation volunteers as those people who travel from their home country to help support wildlife conservation, research, and rehabilitation projects — both in situ and ex situ. While the exact size of the international conservation volunteer market is not known, ninety percent of conservation funding originates and is spent in economically rich countries (Brooks et al. 2006), and hence one would expect these countries constitute the largest percentage of the conservation volunteer market as well. Some conclusions about the size of the Western market could drown from British and US markets. In US, in 2014 , the size of the conservation volunteering market constituted only $2.6 \%$ of the total market (Bureau of Labor Statistics 2014), whereas in Great Britain as Lorimer (2009) notes conservation volunteering does contribute to international conservation but "is not a panacea for comprehensive efforts to protect threatened biodiversity."

Some of the emerging questions in this field are concerned with the effective communication of these opportunities to young people. Conservation projects are a potentially hard sell, especially when young adults are asked to pay for participation in conservation volunteering opportunities offered in remote rural areas with poor infrastructure. While these volunteers are commonly passionate about the environment and want help conserve endangered ecosystems (Schattle 2008; Lorimer 2010), some may additionally seek emotional adventure and excitement (Alba and Williams 2013). A better understanding of these various motives would enable organizations to create campaigns that successfully engage young adults in nature conservation projects. In response to this need, this study seeks to examine if persuasive message type is an important characteristic in appealing to the potential traveler.

While examining motivation to participate in conservation volunteer travel has been examined via a number of theoretical perspectives, the current study utilizes regulatory focus theory. The theory suggests that when using persuasive messages, it is critical to consider the state of mind a person is in (prevention/promotion) and whether the message fits that state of mind. Those in a prevention focus prefer to think about a goal with a loss/nonloss mindset. In contrast, those in a promotion focus have a gain/nongain mentality. This theory is useful in guiding the creation of persuasive campaigns for conservation volunteering because it examines the impact of both the optimistic and pessimistic messaging strategies used in environmental messaging. Moreover, it is a theory used in marketing and advertising research, thus creating a collaborative link between environmental tourism and marketing research. By adopting regulatory focus theory, we reveal yet another possibility for conservation volunteer motivations and its implications for promotional messages for conservation volunteer travel.

Precisely, we seek to learn which types of messages are more effective to market conservation volunteering travel. Will messages focusing on the self-promotion and the unique experience of conservation volunteer be more effective than those calling for the prevention environmental degradation? Will environmental attitudes affect the individual reactions to promotion messages? These questions are important for a 
number of reasons. First, while prevention and promotion messages have been shown to be applicable to public relations or marketing practice and research (e.g., Avnet and Higgins 2006; Kareklas et al. 2012), a gap in knowledge exists about the appeal of prevention/promotion messages to young adults and their power to engage them in travel behaviors such as conservation volunteering. Second, further explication of the impact of promotional persuasive tools on involvement in this activity is needed (e.g., Coghlan 2007; Simpson 2004). Finally, if environmental attitudes affect reception of promotion messages concerning conservation volunteering, this needs to be taken into consideration while creating promotional campaigns for this type of travel.

We intentionally focused this study on Millennials (aging from approximately 17 to 35 years) whose exposure, personally or via media, to ecological devastation and natural disasters has become an essential part of this generation's environmental consciousness (McKay 2010) and turn toward more ethical consumption (Bucic et al. 2012). It has affected their environmental attitudes and triggered an urge to more ethical behavior (McKay 2010; Bucic et al. 2012). Unlike older generations, Millennials appear to be the most environmentally conscious consumers (Smith and Miller 2011; Vermillion and Peart 2010; Bucic et al. 2012). This environmental consciousness is likely to trigger pro-environmental behaviors, such as participation in nature conservation projects (e.g., Stern 2000).

On the other hand, Wismayer (2014) stresses Millennials tendency toward selfabsorption. Out for the ultimate adventure and the selfie to go with it, they are becoming synonymous with travel for the sake of saying they have been somewhere and the ability to one-up their peers (Wismayer 2014). Moreover, Millennials tend to travel for extended periods, visit remote locations, seek enlightening experiences, and travel regardless of economic means (Machado 2014). This is not to argue that Millennials would not seek volunteer travel opportunities. On the contrary, as Malone et al. (2014) suggestion, a quest for positive emotions - and specifically hedonic experiences - can reinforce the informed ethical tourism choices within this group. Opportunities such as conservation volunteering may appeal to their 'you only live once' ('YOLO') mentality and can reward travelers with a tremendous amount of bragging rights. This study contributes to the better understanding of Millennial volunteer travel by exploring how they adhere to regulatory focus in reception of messages promoting conservation projects.

\section{Regulatory Focus}

Regulatory focus theory is concerned with matching goal orientation and goal achievement with psychological state (Higgins 1997, 2000). Working from selfdiscrepancy as a theoretical platform, regulatory focus takes into consideration a person's idealistic desires and dutiful obligations (Higgins 1997). Specifically, when concerned with either seeking a goal or fulfilling an obligation, people tend to fall into a state of regulatory focus (Higgins 1997). More specifically, promotion focus is concerned with "gain/nongain outcomes" and prevention focus is concerned with "nonloss/loss outcomes" (Cesario et al. 2004, p. 389). In the context of volunteer 
travel, a promotion message may focus on gaining a sense of accomplishment from helping an ecosystem. A prevention message, on the other hand, may focus on the duty of care we have toward the environment in order to avert ecological loss. The notion of regulatory fit is accomplished when people match goal orientation and goal achievement (Higgins 2000) and assumes people who are interested and more motivated to fulfill goals when fit is present (Higgins 2000; Shah et al. 1998). In other words, those individuals with a prevention focus feel better about conceptualizing a goal through loss/nonloss means, whereas a promotion-focused individual prefers thinking in gain/nongain means.

When using regulatory fit in persuasive messages, it is important to consider a person's state of mind and whether a message fits that state of mind. People with a prevention focus tend to be more negative and concerned with preventing loss (Markman et al. 2006). In contrast, people with a promotion focus tend to be more positive and concerned with idealistic achievement. Past research found messages utilizing regulatory fit resulted in people feeling better about the decisions they made with regard to the message topic (Higgins 2000; Vaughn et al. 2005).

The mechanism of regulatory fit has been used in the processing of advertising messaging in terms of gain/loss, analytical/imagery, and cognitive/affective message attributes (Roy and Phau 2014; Cornelis et al. 2012; Florack and Scarabis 2006; Park and Morton 2015; Zhao and Pechmann 2007). While regulatory fit theory has been also applied within environmental marketing (Bullard and Manchanda 2013; Kareklas et al. 2012), its usage to test environmental advertising has been limited (e.g., Ku et al. 2013; Roy and Phau 2014). For instance when examining green versus non-green advertising, Ku et al. (2013) found green product messages were perceived as more persuasive by those with a prevention focus than those with a promotion focus. However, in another study, green messages were perceived as more persuasive than non-green messages by both prevention- and promotion-focused individuals (Bullard and Manchanda 2013). In other words, green messages were better perceived regardless of an individual's regulatory focus (Bullard and Manchanda 2013). Similarly, Cornelis et al (2012) research delivered mixed results. Namely, in the case of a rational ad, regulatory congruence (vs. incongruence) effects were found only for prevention-focused people, whereas in the case of an emotional ad, regulatory incongruence (vs. congruence) effects were found only for promotion-focused people.

While it is neither clear nor conclusive why results vary when applying regulatory focus to an environmental context, the overall evidence suggests that promotion-focused individuals should respond better to the messages promoting pro-environmental behaviors. We proposed that for promoting conservation volunteer travel, persons in a promotion focus will better receive of a promotionbased message. In this case, a message touting the benefits of biodiversity, empowering communities, and self-fulfillment should be received better by those in a promotion focus. Thus it is predicted:

H1 For the promotion-focused experimental group, the promotion message will be perceived as (a) more persuasive, (b) less threatening, and (c) increase behavioral intentions compared to the prevention message. 
In terms of conservation volunteer travel, persuasive messages focusing on the preventing environmental damage, and biodiversity preservation should work better on those in a prevention focus. Given the inconsistent results from environmental advertising research, the proposed hypothesis is derived directly from the theory rather than from the past studies. Thus, it is predicted:

H2 For the prevention-focused experimental group, the prevention message will be perceived as (a) more persuasive, (b) less threatening, and (c) increase behavioral intentions compared to the promotion message.

\section{Conservation Volunteering}

Regulatory focus theory provides an interesting and previously untested framework to examine Millenials' responses to persuasive conservation volunteering messages designed to match prevention/promotion focus. While theoretical guidance is useful to understand values and beliefs underlying Millenials motivations to volunteer, past studies identified various types of volunteer motives simply by asking volunteers. This approach resulted in a few competing classifications of volunteers. Callanan and Thomas (2005), for example, distinguished between shallow (in pursuit of personal interests), intermediate, and deep volunteers based on location, project duration, focus (self-interest/altruistic), qualifications, active/passive participation, and contribution to local community. In an attempt to further clarify volunteers' motivations, (Benson and Seibert 2011) pointed out five essential drives: experience of something different/new, meeting international volunteers, learning about countries/cultures, living experience in another country, and mind-opening experience. This distinction between shallow, intermediate, and deep volunteers (Callanan and Thomas 2005) is of interest to organizations coordinating volunteer travel. Smillie (1995) for instance found that for-profit organizations prefer to engage with shallow volunteers, while non-profits favor deep volunteers. Continuing this line of reasoning, Wymer et al. (2010) distinguished two major contemporary volunteer target markets for these organizations: volunteers who are considerate of the community they visit and sensation-seeking volunteer tourists who focus on their own experiences. In an attempt to increase the understanding of the specific factors linked to participation in conservation volunteerism, Eagles and Higgins (1998) proposed that environmental attitudes affect individual's willingness to engage in nature through conservation volunteering.

One of the first and the most influential environmental theories focused on environmental attitudes is the new environmental paradigm (NEP) (Dunlap and Van Liere 1978). It posits people to hold a multitude of views about their rights to control nature, capability to affect it, and planetary boundaries. These views are changing as people learn more about nature (Dunlap and Van Liere 1978; Dunlap et al. 2000). In order to measure these changing attitudes, Dunlap and Van Liere (1978) developed the NEP scale.

Past research has applied the NEP scale mainly to predict various proenvironmental behaviors (e.g., Eagles and Higgins 1998; Luo and Jinyang 2008; 
Sampaio et al. 2012). For instance, Eagles and Higgins (1998) demonstrated positive association between pro-environmental attitudes and one's engagement in pro-environmental behaviors. In a business context, Sampaio et al. (2012) examined how environmental attitudes affect a business organizations' commitment to environmental solutions. Notably, environmental attitudes appear to affect businesses' selection of practices and sensitivity to environmental issues.

In one of the first studies employing the NEP theory to tourism and recreation field, Dunlap and Heffernan (1975) looked at links between type of recreational activity and individual environmental attitudes. They found that those who partake in outdoors recreation are likely to be more concerned about the natural environment. Later, Teisl and O'Brien (2003) added that those who participate in an appreciative recreation activity such as wildlife watching are also more likely to show other environmentally friendly behaviors. This hypothetical link between these types of recreational activities and pro-environmental behavior is precisely why Wearing et al. (2002) examined eco-friendly tourism consumption in a greater detail. Their study confirms a positive correlation between pro-environmental attitudes and more environmentally friendly recreation and tourism. In conclusion, much of the past research suggests that environmental attitudes affect people's intentions to participate in pro-environmental activities; more precisely, these attitudes affect individual's choice of travel and recreation.

Despite a number of studies concerning volunteers' motivations (e.g., Galley and Clifton 2004; Brown and Lehto 2005; Campbell and Smith 2006), a gap in knowledge remains about the relationships between environmental attitudes and participation in conservation volunteering. Support from Millenials is a necessity, and knowing how this generation responds to persuasive marketing messages is key issue. In an attempt to increase the understanding of the effects of promotion/ prevention-focused persuasive messages promoting conservation volunteering, this study seeks to answer the following research question:

RQ1 Will existing environmental attitudes influence promotion versus prevention message reception?

Ethical consumption in tourism is another pertinent and yet understudied issue in contemporary travel and tourism extensively discussed by Malone et al. (2014), who argue that emotional travel experiences inspire consumers to making more ethical travel choices. While this is consistent with earlier findings about travelers' desires to enhance their own personal wellbeing through engagement in volunteering (e.g., Brown and Lehto 2005; Campbell \& Smith 2006; Lepp 2008; Rehberg 2005; Andereck et al. 2012), Malone et al. (2014) additionally emphasize hedonic experiences generate emotional responses that reinforce ethical types of tourism. Their approach is derived from Holbrook and Hirschman (1982) framework for hedonic experiences- "multisensory, fantasy, and emotive aspects of one's experience with products" (p. 92). Holbrook and Hirschman (1982) make several propositions regarding hedonic consumption: emotional desires may dominate consumer choice; consumers ascribe a subjective meaning to products; hedonic consumption is linked to imaginative constructions of reality; and seeking sensory- 
emotive stimulation and seeking cognitive information are two independent dimensions.

Finding the hedonic value may also tap into the potential for promotion-focused messaging to work better compared to prevention-focused messaging. Preventionfocused environmental messages tend to focus on what we may lose with the destruction of ecosystems, while promotion-focused environmental messages can focus on what individuals can gain from conservation volunteering. It is theorized that, regardless of personal regulatory focus, promotion-focused messaging may work better because it captures the hedonic value sought by Millenials. In an attempt to increase the understanding effect of regulatory focus on perceived hedonic value of conservation volunteering, we ask the following research question:

RQ2 How will prevention versus promotion messages influence perceptions of hedonic and utility value?

\section{Methods}

\section{Participants}

Participants $(n=330)$ were drawn from a convenience sample recruited via social media and from students at a large southwestern university. Facebook and Twitter platforms were used to promote the online data collection link; data were collected via a snowball convenience sample. Both participant pools were used to diversify the data. In terms of ethnicity, $17.5 \%$ were Black, $4.8 \%$ Asian, $1.3 \%$ Native American, $62.7 \%$ white, and $13.8 \% \mathrm{mixed} /$ other. Of those, $21 \%$ reported to be Hispanic/Latino. The average age was 22 years. Of the participants, $67 \%$ have traveled outside of the U.S., and $18 \%$ have lived outside the U.S. Of the participants, $29 \%$ were male and $71 \%$ female. $^{1}$

\section{Variables}

\section{Message Evaluation}

The messages were evaluated based on perceived persuasiveness and perceived threat from the message. The perceived persuasiveness measure, derived from Dillard et al. (1996) cognitive appraisal scale, used 7-point Likert-type scale items ( $1=$ strongly disagree, $7=$ strongly agree). Items included evaluations of message quality, accuracy, relevance, and importance. Reliability was excellent ( $\alpha=.925$, $M=4.07, S D=1.16$ ). The perceived threat measure, derived from Dillard and Shen's (2005) scale of perceived threat, used 7-point Likert-type scale items ( $1=$ strongly disagree, $7=$ strongly agree). Items consisted of the message threatened my freedom to choose, the message tried to manipulate me, the message

\footnotetext{
${ }^{1}$ While this balance in the sex of participants was not ideal, an ANOVA analysis of how sex interacted with condition produced non-significant findings. The ANOVA for the interaction on DV persuasiveness $[F(1329)=.023, p=.879]$ and DV behavior $[F(1,329)=.282, p=.595]$ were both non-significant.
} 
tried to make a decision for me, and the message tried to pressure me. Reliability was very $\operatorname{good}(\alpha=.871, M=2.71, S D=1.37)$.

\section{Behavior Intention Inventory}

To measure intentions to participate in environmental volunteer tourism behaviors, an inventory was adapted from previous tourism (Sparks 2007) and consumer (Zaichkowsky 1985) behavior inventory measures. Similar behavior measures have been used also in previous environmental studies (e.g., Kormos and Gifford 2014). The current measure was modified to address potential environmental volunteer tourism behavior. Items included intention to participate in environmental volunteer tourism, learn more about ecovoluntourism, participate in work or school sponsored trips, and explore opportunities on social media. To gauge likely participation in tourism, the measure utilized a 7-point Likert-type scale $(1=$ strongly unlikely, 7 = strongly likely) to predict potential behavior. Reliability was $\operatorname{good}(\alpha=.915$, $M=4.03, S D=1.07$ ).

\section{Perceived Hedonic Value}

The measure, derived from Babin et al. (1994), used 7-point Likert-type scale items ( $1=$ strongly disagree, $7=$ strongly agree $)$. The one-dimensional scale consisted of 12 items aimed at depicting respondents' consumption perceptions of ecovoluntourism. The scale included items gauging whether environmental volunteer tourism looks like a joy, looks truly enjoyable compared to other vacation options, looks exciting, excited at the thought of participating, seems like an escape, enjoy being immersed, enjoy for its own sake not just for skills I gain, seems like a meaningful use of my time, allows me to forget about everyday problems, seems like an adventure, and would be a good time. Reliability was excellent $(\alpha=.947$, $M=4.77, S D=1.27$ ).

\section{$N E P$}

The NEP scale has been employed a number of times to assess environmental attitudes in several countries as well as people from different social categories (e.g., Schultz and Zelezny 1999), to report the awareness of the environmental consequences (Widegren 1998). The scale consists of items asking general environmental topics, measuring the overall relationship between humans and the environment. The scale consisted of 15 items on a 7-point Likert-type scale ( $1=$ strongly disagree, $7=$ strongly agree) pertaining to different environmental views. Reliability was excellent $(\alpha=.912, M=4.59, S D=.63$ ).

\section{Procedure}

This study utilized a 2 (regulatory focus induction: prevention/promotion) $\times 2$ (promotion/prevention message) factorial experimental design. The survey used the 
online data collection service Qualtrics. The study followed ethical requirements under Institutional Review Board regulations.

Participants first completed a consent form before proceeding to the survey. Participants were asked about environmental attitudes NEP before being randomly assigned to an experimental condition, either prevention induction or promotion induction. As prescribed by Higgins et al. (2001), participants were randomly induced into a promotion or prevention focus by either writing about something they ideally wanted to achieve (promotion focus) or writing about an obligation they could not fail to keep (prevention focus).

The survey then presented condition messages in the form of two ads that participants were randomly assigned to view. Experimental advertising messages were created to mimic those that might be used in a social media campaign. The messages utilized the same design, font, and imagery in order to maintain visual continuity. The promotion messages included positive statements focusing on the promotion of an ecological and personal gain from the volunteering experience (Fig. 1a). Conversely, the prevention messages used more dire language focusing on the prevention of ecological loss (Fig. 1b). Message creation was guided by regulatory focus induction language (Higgins et al 2001) to create promotion and prevention tones; they were pilot tested prior to data collection to ensure that the messages were clear. Following the messages, participants answered questions about perceptions of the ad in terms of persuasiveness, reactance, utility, hedonic value, and potential behavior. Demographic information was then collected.

\section{Analysis and Results}

The overall analysis strategy aimed to examine all the variables in one omnibus analysis and then subsequently parse out planned comparisons. A multivariate analysis of variance strategy was adopted to compare the experimental groups, account for the covariate, and analyze the complete set of dependent variables in order to reduce error. We first examined the omnibus multivariate model to assess the overall variable interaction and to address research questions one and two. Two separate factorial MANOVAs were run to assess hypothesis one and two.

To examine the main effects and interaction of the regulation manipulation and message type, an omnibus MANCOVA was run. The covariate of environmental attitudes was included. Box's M (56.69) was not significant $(p=.143)$. There was not a significant multivariate main effect for regulation manipulation, Wilks $\lambda=.991, \mathrm{~F}(5,325)=.610, p=.692$, partial $\eta^{2}=.009$. The interaction between regulation manipulation and message type was not significant, Wilks $\lambda=.982, F(5$, $325)=1.19, p=.311$, partial $\eta^{2}=.018$.

\section{RQ1}

Research question one inquired about how existing environmental attitudes would influence promotion versus prevention message reception. The covariate was significant: environmental attitudes (Wilks $\lambda=.893, F(5,325)=.82, p<.001$, 
a

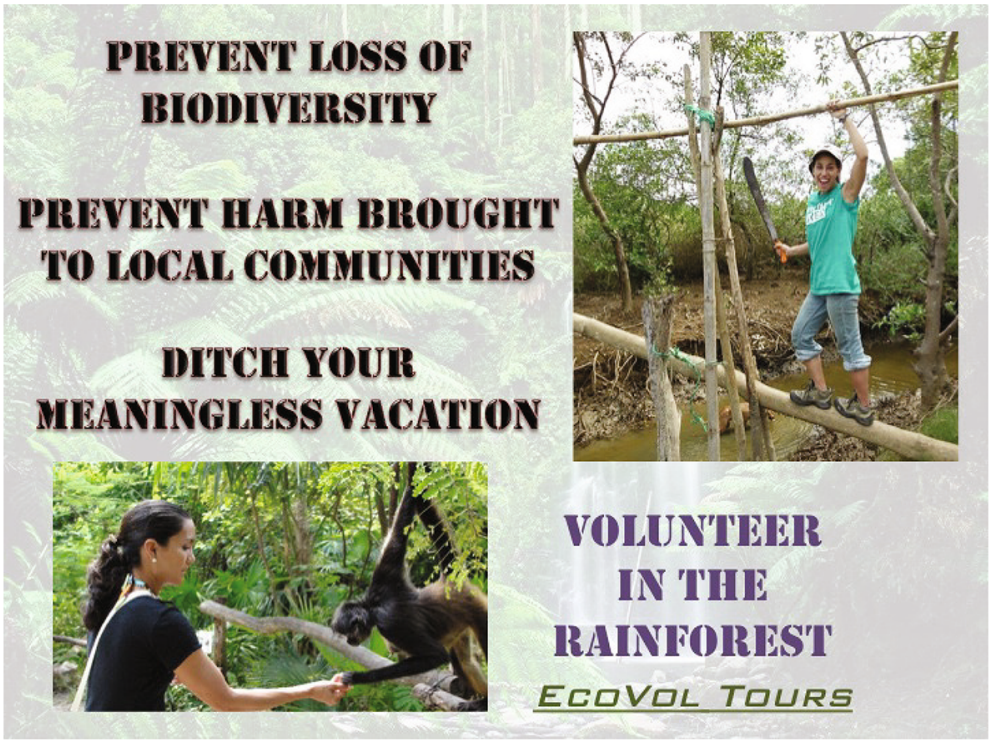

b

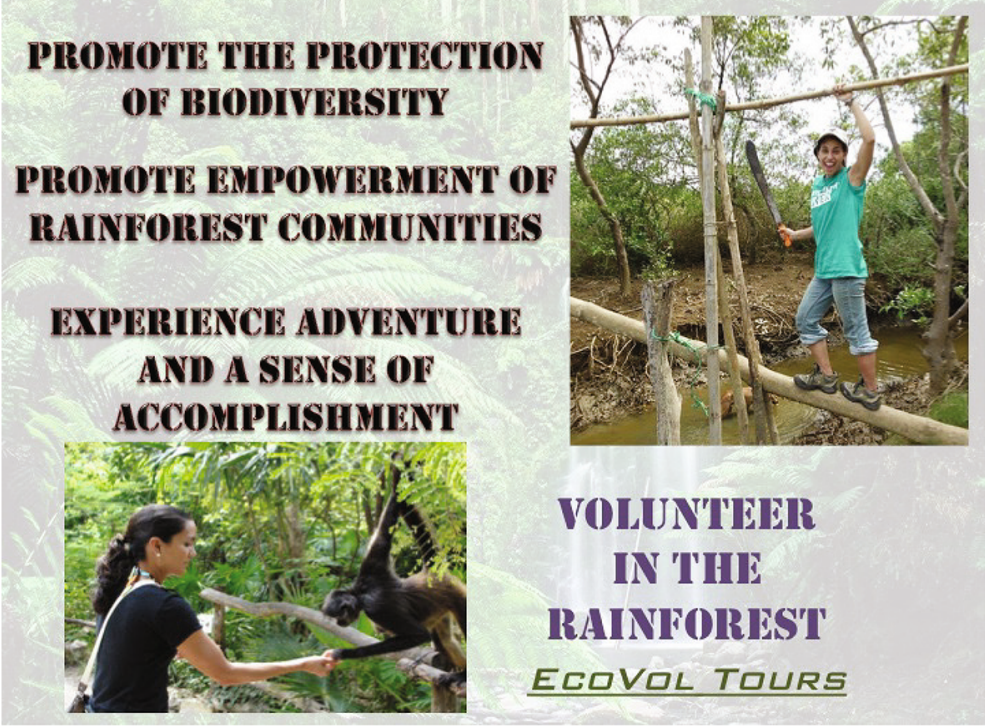

Fig. 1 a Prevention-focused message b Promotion-focused message

partial $\left.\eta^{2}=.107\right)$. There were significant main effects on perceived persuasiveness $\left[F(1,15.79)=11.39, \quad p<.001\right.$, partial $\left.\eta^{2}=.033\right]$, hedonic value $[F(1$, $37.15)=25.27, p<.001$, partial $\left.\eta^{2}=.071\right]$, and behavioral intention $[F(1$, $23.67)=10.94, p<.001$, partial $\left.\eta^{2}=.032\right]$. 


\section{RQ2}

There was a significant multivariate main effect for message type, Wilks $\lambda=.915$, $F(5,325)=6.05, p<.001$, partial $\eta^{2}=.085$. The univariate main effects were significant for perceived persuasiveness $[F(1,15.46)=11.16, p<.001$, partial $\left.\eta^{2}=.033\right]$, perceived threat $\left[F(1,25.55)=13.41, p<.001\right.$, partial $\left.\eta^{2}=.039\right]$, and perceived hedonic value $\left[F(1,5.71)=4.32, p=.05\right.$, partial $\left.\eta^{2}=.012\right]$. This analysis sheds light on research question two, which inquired about how prevention versus promotion messages influence perceptions of hedonic and utilitarian value.

\section{H1}

To further isolate and examine the influence of regulation manipulation on message type, two factorial MANOVAs were run to examine hypothesis one and two. Hypothesis one predicted for the promotion-focused experimental group, the promotion message would be perceived as (a) more persuasive, (b) less threatening, and (c) increase behavioral intentions compared to the prevention message. To examine the promotion focus manipulation, a subset of the data was selected and analyzed. A one-way MANOVA was run examining message type on the dependent variables. There was a significant multivariate main effect for message type, Wilks $\lambda=.912, F(5,164)=3.179, p=.009$, partial $\eta^{2}=.088$ (Box's $M=16.49$, $p=.384)$. The univariate main effects were significant for perceived persuasiveness $\left[F(1,6.15)=4.09, \quad p=.045\right.$, partial $\left.\eta^{2}=.024\right]$ and perceived threat $[F(1$, 21.72) $=10.33, p=.002$, partial $\left.\eta^{2}=.058\right]$.

In a promotion focus, the promotion message was seen a more persuasive $(M=4.187)$ compared to the prevention message $(M=3.807)$. Moreover, in a promotion focus, the promotion message was seen as less threatening $(M=2.579)$ compared to the prevention message $(M=3.285)$. The univariate main effects were not significant for hedonic and behavioral intention. In the promotion focus, the promotion message was not perceived as having significantly higher hedonic value $(M=4.728)$ compared to the prevention message $(M=4.701)$. Moreover, the promotion message did not inspire potential behavior $(M=3.488)$ significantly more than the prevention message $(M=3.663)$.

\section{H2}

Hypothesis two predicted for the prevention-focused experimental group, the prevention message would be perceived as (a) more persuasive, (b) less threatening, and (c) increase behavioral intentions compared to the promotion message. To examine the prevention focus manipulation, a subset of the data was selected and analyzed. A one-way MANOVA was run examining message type on the dependent variables. There was a significant multivariate main effect for message type, Wilks $\lambda=.896, F(5,160)=3.727, p=.003$, partial $\eta^{2}=.104 \quad$ (Box's $M=25.27$, $p=.06)$.

The univariate main effects were significant for perceived persuasiveness $(F(1$, $10.17)=7.52, p=.007$, partial $\left.\eta^{2}=.044\right)$, perceived threat $[F(1,7.64)=4.30$, 
$p=.04$, partial $\left.\eta^{2}=.026\right]$, and perceived hedonic value $[F(1,11.61)=7.87$, $p=.006$, partial $\left.\eta^{2}=.046\right]$. In the prevention focus, the promotion message was perceived as significantly more persuasive $(M=4.371)$ compared to the prevention message $(M=3.876)$. Moreover, in the prevention focus, the promotion message was perceived as significantly less threatening $(M=2.604)$ compared to the prevention message $(M=3.033)$. In terms of perceived hedonic value while in a prevention focus, the promotion message was perceived to have higher hedonic value $(M=5.045)$ compared to the prevention message $(M=4.516)$. The univariate main effect was not, however, significant for behavioral intention. In the prevention focus, the promotion message was not perceived as inspiring significantly higher behavioral intention $(M=3.766)$ compared to the prevention message $(M=3.593)$.

\section{Discussion}

A growing number of young people are making informed choices and contributing to the well being of the natural environment through conservation volunteering (Lorimer 2010; McDougle et al. 2011). Conservation volunteering travel is an increasingly popular way for Millenials, who are currently the most environmentally conscious consumers (Smith and Miller 2011; Vermillion and Peart 2010), to engage in global citizenship (Lorimer 2010; McDougle et al. 2011). However, as experts want a typically consistent multiple-year increase in these forms of civic engagement, organizations must continuously reinforce the importance of young adults pursuing environmental and conservation activities (Eisner 2005).

With the goal of applying regulatory focus theory, this study sought to illuminate the effects of persuasive message for promoting the conservation volunteering experience to a Millennial audience. The first hypothesis pertained to the usefulness of a promotion focus induction mixed with a promotion-focused message, while the hypothesis two pertained to the usefulness of a prevention focus induction mixed with a prevention-focused message. Moreover, research question one pertained to the effect of environmental attitudes on reception of promotion/prevention persuasive messages. Research question two pertained to the effect of these messages on perceived hedonic value of conservation volunteering.

Parsing out prevention and promotion induction conditions revealed interesting trends. Namely, regulatory induction was not significant, meaning that response to promotion/prevention messages is not affected by individual's regulatory focus. On the contrary, the promotion message worked better for both groups (prevention- or promotion-focused individuals), meaning it was perceived as more persuasive. It also had higher hedonic value and produced less reactant attitudes. Respondents thought the positive message involved more enjoyable options and held less negative thoughts about the message. It evoked the primal desires of adventure and excitement about the type of experiences who can enjoy by participating in conservation projects. The results suggest promotion messages are better received (more persuasive) because they induce expectations in line with general view of conservation volunteering as a hedonic experience (Malone et al. 2014). 
These results fall in line with some past research presenting conservation volunteering travel as a primarily emotional hedonic experience (e.g., Alba and Williams 2013) or studies of propensity to engage in pro-environmental activities among visitors to wildlife areas (Lemelin et al. 2008). In this, light conventional tourism stands for more traditional consumer values of material possessions or personal wealth (Fournier and Richins 1991) leading to convenience, variety, quality, or low price seeking behavior, while travel for conservation volunteering is associated with positive emotions and emotional desires. These positive emotional desires translate into a person's need for pleasurable and interesting experiences (Pearce 2009; Alba and Williams 2013; Malone et al. 2014).

Lemelin et al. (2008) suggested that research has made a faulty assumption that visitors to wildlife areas share positive environmental ethics, biocentric values, and intrinsic motives (e.g., Acott et al. 1998; Honey 1999). They found differences in the propensity to engage in pro-environmental behavior for the wildlife tourism specialization groups with connoisseurs and enthusiasts scoring significantly higher than novices (Lemelin et al. 2008). It could be concluded that visitation to wildlife areas may not necessarily be motivated by willingness to engage in proenvironmental behavior, but instead is motivated by a desire of adventure and hedonic experiences. Moreover, Lemelin et al. (2008) suggest specialization of a visitor to wildlife area that may reflect conspicuous consumption (i.e., inspirational overbuying or social status) rather than 'commitment to or involvement in an activity' (e.g., McIntyre and Pigram 1992; 4 in Lemelin et al. (2008)). This corresponds with our findings where conservation volunteers demonstrated desire of hedonic experience rather than commitment to nature conservation.

Reflecting on previous regulatory focus research in a context of environmental communication, this study produced both congruent and incongruent results. While Bullard and Manchanda (2013) argue sustainable marketing makes people more prevention focused and they prefer prevention messages; our research contradicts their findings as we found prevention-focused people considered the promotion message to be more persuasive, generating less perceived threat, and having higher hedonic value.

Finally, with regard to the question concerning the relationship between environmental attitudes and perception of conservation volunteering messages, we found that these attitudes do affect the perception of message persuasiveness, the perception of hedonic value of this type of volunteering, as well as behavioral intention to participate in this pro-environmental activity. While the character of this relationship needs to be further explored in future, our study is the first one of its kind to show this important effect of environmental attitudes on individuals' responses to conservation volunteering messages. This could further be tested, for example, in terms of different groups of volunteers categorized according to expressed environmental attitudes or relationship between different attitudes and participation in conservation volunteering. This part of our research was guided by studies of the relationship between environmental attitudes and pro-environmental behaviors which employed the NEP theory and our findings are in line with this past research (e.g., Eagles and Higgins 1998; Luo and Jinyang 2008; Sampaio et al. 2012). Moreover, not only does it contribute to the explanation of what factors 
affect reception of pro-environmental promotional messages, but also it provokes further discussion of the relevance of environmental attitudes, and hedonic desires.

\section{Conclusion}

With declining public funding to support nature conservation, building continuous commitment to nature through volunteering is key to addressing a range of societal environmental priorities such as enhancing biodiversity and building sustainable communities (e.g., Anheier and Salomon 1999; Rodriguez et al. 2007; Wearing and McGehee 2013). Numerous studies have explored volunteering from a tourism perspective (Callanan and Thomas 2005; Raymond and Hall 2008; Soderman and Snead 2008; Wickens 2011), and yet the majority focused predominantly on the values of the volunteer and how these values translate into motives (e.g., Brown and Lehto 2005; Campbell \& Smith 2006; Wearing 2001). In this line of reasoning, we explored the effects of person's regulatory focus on their perception of persuasive messages. We found positive messages are perceived as more persuasive regardless of the respondent's regulatory focus and that preexisting environmental attitudes affect how messages promoting conservation volunteering are received.

These results are of importance to scholars because they challenge how we traditionally think prevention and promotion focus works in marketing messages. Namely, individual regulatory focus is not a factor driving response to messages promoting conservation volunteering. For Millennials, environmental attitudes and desires for hedonic experience appear to be affecting their response to messages. These findings could inform organizations which strive to attract committed individuals who are also willing to pay for the experience.

These results are also of importance to organizations marketing campaigns because environmental messages tend to be framed as prevention messages which is the contrary to what this study's results suggest to do. Namely, communications that focus on natural disasters or environmental apocalypse (i.e., ice caps melting or animals becoming extinct) appear to be less persuasive than positively framed messages focused on self-promotion, adventure as well as the support to those. Concentrating on positive aspects would be strategically beneficial.

Finally, this study points out that Millenials are hedonistic in their lifestyle choices which has some important implications in terms of conservation volunteering. It is plausible that conservation volunteering is seen as a form of ethical form of tourism or ethical leisure as proposed by Malone et al. (2014). This could be an indication of how eco-awareness influences Millennials travel choices This finding also supports Lorimer's (2009) argument concerning limited impact of conservation volunteering on international conservation in general, suggesting that this is mainly due to volunteer travelers being more interested in remote and unique and therefore attractive ecosystems rather than domestic conservation projects. Consuming ecosystems through volunteering in conservation projects internationally satisfies Millenials who needs to explore, remote, and exotic places and simultaneously contributing to their need to participate in conservation of endangered ecosystems and species. 


\section{Limitations}

Although this study is the first to look at prevention/promotion focus and message reception in the context of conservation volunteering, it is not without limitations. First, this study utilized self-reporting of intentions to participate in conservation volunteering. While this type of measure has previously been used in environmental context (e.g., Kormos and Gifford 2014), future research can attempt to track actual ethical tourism behaviors such as conservation volunteering and the individual characteristics such as self-efficacy (Bandura 1977) that may affect it, or examine the nuance between ecological stewardship versus perceived consumer hedonic value in the context of conservation volunteering.

Second, this study presumed greater environmental consciousness among Millenials. However, research on eco-awareness of Millennials is rather scarce, and no global surveys results are available at this point of time. We acknowledged this as the limitation of the study and possible future research. Third, a convenience sample was used via social media (Facebook and Twitter promotion) in addition to student participants. While the experimental design and random assignment to condition improve the internal validity, convenience samples are a limitation to the external validity. Future should seek additional participant selection techniques like professional recruitment services (e.g., Qualtrics panels).

Open Access This article is distributed under the terms of the Creative Commons Attribution 4.0 International License (http://creativecommons.org/licenses/by/4.0/), which permits unrestricted use, distribution, and reproduction in any medium, provided you give appropriate credit to the original author(s) and the source, provide a link to the Creative Commons license, and indicate if changes were made.

\section{Appendix}

See Table 1.

Table 1 Promotion and prevention focus

\begin{tabular}{lll}
\hline Dependent variable & Message type & Promotion \\
\cline { 3 - 3 } & Prevention & \\
\hline Promotion focus & & 4.187 \\
Persuasiveness* & 3.807 & 2.579 \\
Threat* & 3.285 & 4.728 \\
Hedonic & 4.700 & 3.488 \\
Behavior & 3.663 & 4.371 \\
Prevention focus & & 2.604 \\
Persuasiveness* & 3.876 & 5.045 \\
Threat* & 3.033 & 3.766 \\
Hedonic* & 4.516 & \\
Behavior & 3.593 & \\
\hline
\end{tabular}

$* p=.05$ 


\section{References}

Acott, T. G., La Trobe, H. L. \& Howard, S. H. (1998). An evaluation of deep ecotourism and shallow ecotourism. Journal of Sustainable Tourism, 6(3), 238-253.

Alba, J. W., \& Williams, E. F. (2013). Pleasure principles: A review of research on hedonic consumption. Journal of Consumer Psychology, 23(1), 2-18.

Andereck, K., McGehee, N. G., Lee, S., \& Clemmons, D. (2012). Experience expectations of prospective volunteer tourists. Journal of Travel Research, 51(2), 130-141.

Anheier, H. K., \& Salomon, L. M. (1999). Volunteering in cross-national perspective: Initial comparisons. Law and Contemporary Problems, 62, 43-65.

Avnet, T., \& Higgins, E. T. (2006). How regulatory fit affects value in consumer choices and opinions. Journal of Marketing Research, 43, 1-10.

Babin, B. J., Darden, W. R., \& Griffin, M. (1994). Work and/or fun: Measuring hedonic and utilitarian shopping value. Journal of Consumer Research, 20(4), 644-656.

Bandura, A. (1977). Self-efficacy: Toward a unifying theory of behavioral change. Psychological Review, 84(2), 191-215.

Benson, A., \& Seibert, N. (2011). Volunteer tourism: Motivations of German participants in South Africa. Annals of Leisure Research, 12(3-4), 295-314.

Brooks, T. M., Mittermeier, R. A., da Fonseca, G. A. B., Gerlach, J., Hoffmann, M., Lamoreux, J. F., et al. (2006). Global biodiversity conservation priorities. Science, 313, 58-61.

Brown, S., \& Lehto, X. (2005). Travelling with a purpose: Understanding the motives and benefits of volunteer vacations. Current Issues in Tourism, 8(6), 479-496.

Bucic, T., Harris, J., \& Arli, D. (2012). Ethical consumers among the Millennials: A cross-national study. Journal of Business Ethics, 110(1), 113-131.

Bullard, O., \& Manchanda, R. V. (2013). Do sustainable products make us prevention focused? Mark Lett, 24(2), 177-189.

Bureau of Labor Statistics (2014) U.S. Department of Labor, The Economics Daily, Volunteering in 2014 on the Internet. Retrieved October 17 from 2016. http://www.bls.gov/opub/ted/2015/volunteeringin-2014.htm

Callanan, M., \& Thomas, S. (2005). Volunteer tourism: Deconstructing volunteer activities within a dynamic environment. In M. Novelli (Ed.), Niche tourism: Contemporary issues, trends and cases (pp. 183-200). Amsterdam: Elsevier.

Campbell, L. M., \& Smith, C. (2006). What makes them pay? Values of volunteer tourists working for sea turtle conservation. Environmental Management, 38(1), 84-98.

Cesario, J., Grant, H., \& Higgins, E. T. (2004). Regulatory fit and persuasion: transfer from "feeling right.”. Journal of Personality and Social Psychology, 86, 338-404.

Coghlan, A. (2007). Towards an integrated image-based typology of volunteer tourism organizations. Journal of Sustainable Tourism, 15(3), 267-287.

Cornelis, E., Adams, L., \& Cauberghe, V. (2012). The effectiveness of regulatory (in)congruent ads: The moderating role of an ad's rational versus emotional tone. International Journal of Advertising, 31, $397-420$.

Dillard, J. P., Kinney, T. A., \& Cruz, M. G. (1996). Influence, appraisals, and emotions in close relationships. Communication Monographs, 63, 105-130.

Dillard, J. P., \& Shen, L. (2005). On the nature of reactance and its role in persuasive health communication. Communication Monographs, 72, 144-168.

Dunlap, R. E., \& Heffernan, R. B. (1975). Outdoor recreation and environmental concern: an empirical examination. Rural Sociology, 40(1), 18-30.

Dunlap, R. E., \& Van Liere, K. D. (1978). The "new environmental paradigm": A proposed measuring instrument and preliminary results. Journal of Environmental Education, 9(1), 10-19.

Dunlap, R. E., Van Liere, K. D., Mertig, A. G., \& Jones, R. E. (2000). Measuring endorsement of the new environmental paradigm: A revised NEP scale. Journal of Social Issues, 56, 425-442.

Eagles, P. F. J., \& Higgins, B. R. (1998). Ecotourism market and industry structure. In K. Lindberg, M. E. Wood, \& D. Engeldrum (Eds.), Ecotourism: A guide for planners and managers (pp. 11-43). North Bennington, VT: The Ecotourism Society.

Eisner, D. (2005). The real challenge for volunteerism. Chronicle of Philanthropy, 17(20), 51-52.

Florack, A., \& Scarabis, M. (2006). How advertising claims affect brand preferences and category-brand associations: The role of regulatory focus. Psychology \& Marketing, 23(9), 741-755. 
Fournier, S., \& Richins, M. L. (1991). Some theoretical and popular notions concerning materialism. Journal of Social Behavior and Personality, 6, 403-414.

Galley, G., \& Clifton, J. (2004). The motivational and demographic characteristics of research ecotourists: Operation Wallacea volunteers in southeast Sulawesi, Indonesia. Journal of Ecotourism, 3(1), 69-82.

Higgins, E. T. (1997). Beyond pleasure and pain. American Psychologist, 52, 1280-1300.

Higgins, E. T. (2000). Making a good decision: Value from fit. American Psychologist, 55, 1217-1230.

Higgins, E. T., Friedman, R. S., Harlow, R. E., Idson, L. C., Ayduk, O. N., \& Taylor, A. (2001). Achievement orientations from subjective histories of success: Promotion pride versus prevention pride. European Journal of Social Psychology, 31, 3-23.

Holbrook, M. B., \& Hirschman, E. C. (1982). The experiential aspects of consumption: Consumer fantasies, feelings, and fun. Journal of Consumer Research, 9, 132-140.

Honey, M. (1999). Ecotourism and Sustainable Development: Who Owns Paradise? Washington, DC: Island Press.

Kareklas, I., Carlson, J. R., \& Muehling, D. D. (2012). The role of regulatory focus and self-view in "green" advertising message framing. Journal of Advertising, 41(4), 25-39.

Kormos, C., \& Gifford, R. (2014). The validity of self-report measures of pro-environmental behavior: A meta-analytic review. Journal of Environmental Psychology, 40, 359-371.

$\mathrm{Ku}, \mathrm{H} ., \mathrm{Kuo}, \mathrm{C}$., Wu, C., \& Wu, C. (2013). Communicating green marketing appeals effectively: The role of consumers' motivational orientation to promotion versus prevention. Journal of Advertising, 41(4), 41-50.

Lemelin, R. H., Fennell, D., \& Smale, B. (2008). Polar bear viewers as deep ecotourists: How specialised are they? Journal of Sustainable Tourism, 16(1), 42-62.

Lepp, A. (2008). Discovering self and discovering others through the Taita Discovery Centre Volunteer Tourism Programme Kenya. In K. Lyons \& S. Wearing (Eds.), Journeys of discovery in volunteer tourism: International case study perspectives (pp. 86-100). Wallingford, UK: CABI.

Lorimer, J. (2009). International conservation volunteering from the UK: What does it contribute? Oryx, $43(3), 352-360$.

Lorimer, J. (2010). International conservation 'volunteering' and the geographies of global environmental citizenship. Political Geography, 29(6), 311-322.

Luo, Y., \& Jinyang, D. (2008). The new environmental paradigm and nature-based tourism motivation. Journal of Travel Research, 46(4), 392-402.

Machado, A. (2014). How Millennials are changing travel. The Atlantic. Accessed June 9, 2015.

Malone, S., McCabe, S., \& Smith, A. P. (2014). The role of hedonism in ethical tourism. Annals of Tourism Research, 44, 241-254.

Markman, K. D., McMullen, M. N., Elizaga, R. A., \& Mizoguchi, N. (2006). Counterfactual thinking and regulatory fit. Judgment and Decision Making, 1, 98-107.

McDougle, L., Greenspan, I., \& Handy, F. (2011). Generation green: Understanding the motivations and mechanisms influencing young adults' environmental volunteering. International Journal of Nonprofit and Voluntary Sector Marketing, 16(4), 325-341.

McKay, L. (2010). Generation green. CRM Magazine, 14(4), 12-13.

Park, S., \& Morton, C. R. (2015). The role of regulatory focus, social distance, and involvement in antihigh-risk drinking advertising: A construal-level theory perspective. Journal of Advertising, 44(4), 338-348.

Pearce, P. L. (2009). The relationship between positive psychology and tourist behaviour studies. Tourism Analysis, 14, 37-48.

Raymond, E. M., \& Hall, C. M. (2008). The development of crosscultural (mis)understanding through volunteer tourism. Journal of Sustainable Tourism, 16(5), 530-543.

Rehberg, W. (2005). Altruistic individualists: Motivations for international volunteering among young adults in Switzerland. VOLUNTAS: International Journal of Voluntary and Nonprofit Organizations, 16(2), 109-122.

Rodriguez, J. P., Taber, A. B., Daszak, P., Sukumar, R., Valladares-Padua, C., Padua, S., et al. (2007). Globalization of conservation: A view from the south. Science, 317, 755-756.

Roy, R., \& Phau, I. (2014). Examining regulatory focus in the information processing of imagery and analytical advertisments. Journal of Advertising, 43(3), 371-381.

Sampaio, A. R., Rhodri, T., \& Font, X. (2012). Why are some engaged and not others? Explaining environmental engagement among small firms in tourism. International Journal of Tourism Research, 14, 235-249. 
Schattle, H. (2008). The practices of global citizenship. Lanham, MD: Rowman \& Littlefield.

Schultz, P. W., \& Zelezny, L. C. (1999). Values as predictors of environmental attitudes: Evidence for consistency across 14 countries. Journal of Environmental Psychology, 19, 255-265.

Shah, J., Higgins, E. T., \& Friedman, R. S. (1998). Performance incentives and means: How regulatory focus influences goal attainment. Journal of Personality and Social Psychology, 74, 285-293.

Simpson, K. (2004). 'Doing development': The gap year volunteer-tourists and a popular practice of development. Journal of International Development, 16, 681-692.

Smillie, I. (1995). The alms bazaar: Altruism under fire-non-profit organizations and international development. London: IT Publications.

Smith, C., \& Miller, H. (2011). Accessing the food system in urban and rural Minnesotan communities. Journal of Nutrition Education and Behavior, 43(6), 492-504.

Soderman, N., \& Snead, S. (2008). Opening the gap: The motivation of gap year travellers to volunteer in Latin America. In K. D. Lyons \& S. Wearing (Eds.), Journeys of discovery in volunteer tourism: International case study perspectives (pp. 118-129). Wallingford, UK: CABI.

Sparks, B. (2007). Wine tourism consumer questionnaire [Database record]. Retrieved from PsycTESTS. doi:10.1037/t26698-000.

Stern, C. P. (2000). Toward a coherent theory of environmentally significant behavior. Journal of Social Issues, 56(5), 407-424.

Teisl, M. F., \& O'Brien, K. (2003). Who cares and who acts? Outdoor recreationists exhibit different levels of environmental. Environment and Behavior, 35(4), 506-522.

Vaughn, L. A., O’Rourke, T., Schwartz, S., Malik, J., Petkova, Z., \& Trudeau, L. (2005). When two wrongs can make a right: Regulatory nonfat, bias, and correction of judgments. Journal of Experimental Social Psychology, 42, 654-661.

Vermillion, L. J., \& Peart, J. (2010). Green marketing: making sense of the situation. Allied Academies International Conference: Proceedings of the Academy of Marketing Studies, 15(1), 68-72.

Wearing, S. (2001). Volunteer tourism: Experiences that make a difference. Oxon: CABI Publishing.

Wearing, S., Cynn, S., Ponting, J., \& McDonald, M. (2002). Converting environmental concern into ecotourism purchases: A qualitative evaluation of international backpackers in Australia. Journal of Ecotourism, 1, 133-148.

Wearing, S., \& McGehee, N. G. (2013). Volunteer tourism: A review. Tourism Management, 38, $120-130$.

Wickens, E. (2011). Journeys of the self: Volunteer tourists in Nepal. In A. M. Benson (Ed.), Volunteer tourism: Theoretical framework to practical applications (pp. 42-52). London: Routledge.

Widegren, O. (1998). The new environmental paradigm and personal norms. Environment and Behavior, $30(1), 75-100$.

Wismayer, H. (2014). When tourism turns into narcissism. Vice. Retrieved June 9, 2015.

Wymer, W. W., Jr., Self, D. R., \& Findley, C. S. C. (2010). Sensation seekers as a target market for volunteer tourism. Service Marketing Quarterly, 31(3), 348-362.

Zaichkowsky, J. L. (1985). Measuring the involvement construct. Journal of Consumer Research, 12, 341-352.

Zhao, G., \& Pechmann, C. (2007). The impact of regulatory focus on adolescents' response to antismoking advertising campaigns. Journal of Marketing Research, 44, 671-687. 